\title{
Immaterial Public Order: Legal Response to Social Crisis?
}

\author{
Marie-Odile Peyroux-Sissoko*
}

\begin{abstract}
This contribution aims to analyze the concept of the immaterial public order and its use in law and jurisprudence in the context of social crises. It understands this concept as an ancient response becoming part of the formalized legal order, to the societies in crises. The different legal orders must respond such challenges as the globalization, terrorism or financial crises of nowadays. The paper proposes to understand the immaterial public order as an instrument of law that helps the cooperation of the different normative orders as e.g. of the domestic legal order and the European law or international law. But this concept is useful not only to regulate the relationship between different legal orders but also to settle the relationship between the legislator and the constitutional judge. The analysis offers a general doctrinal approach while focusing on the French case.
\end{abstract}

Keywords: immaterial public order, fundamental rights of persons, crisis management

\section{INTRODUCTION}

Globalisation favours the free movement of persons, goods and ideas. Trade between States is facilitated. However, whereas borders have been getting ever less significant and even disappearing for years within the European Union, the current geopolitical situation - Syria and the corresponding wave of immigration, for instance - brings certain States to erect new ones. ${ }^{1}$ And in this world, ${ }^{2}$ which is getting reorganised and is witnessing the return of Empires, terrorism strikes. France, ${ }^{3}$ Tunisia, ${ }^{4}$ Chad, ${ }^{5}$ Cameroon... ${ }^{6}$ how many more countries could we enumerate in which there have been attacks since January 2015 alone?

We notice two intensifying simultaneous conflicting movements that destabilise the States already shaken by this troubled global context.

On the one hand, the States transfer more and more competences to supranational bodies, such as the European Union. Concerning this point, the questions of terrorism and security are revelatory of the integration between the States, in so far as they demand responses, intervention at an intergovernmental scale. The integration is also real on the level of the Council of Europe, the European Court of Human Rights (hereinafter ECHR) giving the interpretations of the Convention that the States must respect under the States must respect under penalty of sanctions. As a result of these integrations, the States sometimes find themselves 'diluted' in a space larger than them, that national governments imagine not being able to control anymore. And then resistance emerges, as the French Constitutional Council's recognition of the concept of constitutional identity in 2006 shows. $^{7}$

* Doctorante ATER en Droit public, Centre de recherche en Droit constitutionnel (CRDC), Institut des Sciences Juridique et Philosophique de la Sorbonne (ISJPS-UMR 8103), Université Paris 1 Panthéon-Sorbonne. Email: peyroux_mo@yahoo.fr

1 This is the case (all situations taken together) of Germany, Austria, Hungary and Russia.

2 Cf. in particular Del Valle (2014). See also Mathieu (2013).

3 Attacks of 7 and 9 January 2015 against Charlie Hebdo and the shop Hyper Cacher.

${ }^{4}$ Attacks of 18 March and 27 June 2015 at the Bardo Museum and in Sousa.

5 Suicide attacks of 11 July 2015 in N'djamena.

${ }^{6}$ Double suicide attack of 13 September 2015 in Kolofata.

7 Law on authors' rights and related rights in the information society no 2006-540 DC (Constitutional Council, 27 July 2006) 'Considering that (...) the transposition of a directive shall not 
On the other hand, at the opposite of this 'headlong rush' of the States into supranational structures, identity claims are becoming ever stronger within the state structure itself. The elections of 27 September 2015 at the Parliament of Catalonia that resulted in proindependence supporters obtaining the majority of seats are exemplary of these claims, just like the referendum in Scotland on whether they should or should not leave the United Kingdom. ${ }^{8}$ The need to take identities into consideration, be it cultural, sexual, religious, ethnic, local or national identity... pushes the state structure into a real crisis.

This observation, though certainly a bit hasty, permits, however, to see that the challenges currently facing the States are manifold and coherent. Economic, social, cultural, security, identity challenges... How does French legislation tackle them?

Facing these challenges, the law uses concepts enabling the different judicial stakeholders (legislator, regulatory authority, judge...) to take into consideration political problems and to deal with them in a judicial manner. Thus, the concept of public order, in its administrative and material sense - that is, the public order that public authority should protect by ensuring public security, health and tranquillity ${ }^{9}$ - permits facing the security challenge. Known from European Union law, ${ }^{10}$ but also from conventional law, ${ }^{11}$ this concept restricts and protects individual freedoms at the same time. The relationship that public order creates is, thus, classic: security is opposed to freedom and, depending on the circumstances brought about by the period in which the public authority intervenes, for example, in the event of constant terrorist threat, society may appear to lean rather towards security than towards freedom.

The material public order is, however, not enough to meet all the challenges the State is facing: questions pertaining to culture, values, assertions of identity cannot be legally reduced to the public order of security, health and tranquillity. In order to legally grasp them, French law has gone beyond material aspects by introducing other concepts, more difficult to chart because they are not defined at best or do not even have a name, in the worst case.

Such is the case of the concept of constitutional identity that would enable France to oppose certain supranational rules, and which, in any case, permitted to avert the European Union about the existence of a tool in France that reserves jurisdiction, and thus the sovereignty of the State.

This is also the case of the concept of immaterial public order, which we understand as the non-material counterpart of the material public order we have just referred to, that is, as the concept enabling the restriction of individual freedoms outside all material disturbances, seeking to protect a superior element, and understood as a superior requirement. This

conflict with an inherent rule or principle of French constitutional identity, except if the constituent had agreed to it.' For more on the concept seen not as resistance but as conciliation, see Guerrini (2014), Levade (2010) 109, Millet, (2013), Quesnel (2015).

${ }^{8}$ Referendum on the independence of Scotland, 18 September 2014.

9 Article L. 2212-2 of the Local Authorities General Code.

10 Article 4 paragraph 2 of the Treaty on the European Union: the Union shall respect the equality of Member States before the Treaties as well as their national identities, inherent in their fundamental structures, political and constitutional, inclusive of regional and local self-government. It shall respect their essential State functions, including ensuring the territorial integrity of the State, maintaining law and order and safeguarding national security. In particular, national security remains the sole responsibility of each Member State.

11 Paragraph 2 of Articles 8 to 11 and Article 15 (however, not explicitly) of the European Convention for the Protection of Human Rights and Fundamental Freedoms. 
concept, already present in law without being named, nevertheless, was implicitly enshrined by the constitutional judge in the decision 613 DC of 7 October 2010 on the law prohibiting the concealment of the face in public spaces. ${ }^{12}$ The law was afterwards declared valid by the ECHR in its judgment SAS vs. France of 1 July $2014 .{ }^{13}$

Is the concept of immaterial public order a legal response given to this social crisis? The analysis of the concept shows that not only is the immaterial public order a response given to social crisis (1), but it is also a regulatory instrument managing the relationship between the normative authorities (2).

\section{THE IMMATERIAL PUBLIC ORDER AS RESPONSE TO SOCIAL CRISIS}

The immaterial public order is a response given in the event of a crisis and when classic legal instruments are insufficient and do not permit to deal with the issue. The competent authority will have to respond to the prejudice to a social code caused by an individual freedom, a value upon which society normally agrees. In other words, the concept enables the competent authority in the field of limitation of individual liberties to respond to the situation in which the individual, exercising their freedom, infringes a social taboo. In this case, the competent authority will limit the exercised freedom based on the immaterial public order, which enables thus both to put an end to the violation of the social taboo and to legally formalise it. The response thus provided is a short-term one that authority only uses when the circumstances of the case, impossible to tackle with existing legal tools, require it. Therefore, this response is not new (2.1) and tends to get formalised (2.2) because still valid.

\subsection{An Old Response}

The immaterial public order as justification to the limitation of individual freedoms is not new. Since the beginning of the $20^{\text {th }}$ century, the administrative authority prohibits certain behaviours and activities in order to protect the elements not taken into account by the law,

12 Law on prohibiting the concealment of the face in public spaces no 2010-613 DC (Constitutional Council, 7 October 2010)

Considering that Articles 1 and 2 of the law referred are intended to respond to the emergence of until then extraordinary practices consisting of the concealment of the face in public spaces; that the legislator felt that such practice may pose a danger to public safety and disregards the minimum requirements of life in a society; that it also felt that women who conceal their faces, voluntarily or otherwise, are in a situation of exclusion and inferiority, clearly incompatible with the constitutional principles of freedom and equality; that by adopting the referred provisions, the legislator completed and generalised rules that had been, until then, reserved for specific situations, in order to protect the public order.

13 SAS vs. France no 43835/11 (ECtHR, 1 July 2014)

157. Consequently, having regard in particular to the breadth of the margin of appreciation afforded to the respondent State in the present case, the Court finds that the ban imposed by the Law of 11 October 2010 can be regarded as proportionate to the aim pursued, namely the preservation of the conditions of "living together" as an element of the "protection of the rights and freedoms of others". The impugned limitation can thus be regarded as "necessary in a democratic society". This conclusion holds true with respect both to Article 8 of the Convention and to Article 9. Accordingly, there has been no violation either of Article 8 or of Article 9 of the Convention. 
while the activities in question do not bring about problems, or even the risk of material problems.

In 1924 for example, boxing matches were prohibited because the authority felt they were contrary to 'moral hygiene'. ${ }^{14}$ In 1930, the mayor of a seaside resort decided to prohibit walking shirtless in town. ${ }^{15}$ The famous Lutétia judgment rendered in the fifties, in which the Council of State in the role of the administrative court accepted that the public authority prohibit the distribution of a film in the name of 'public morals', appears in the same vein. ${ }^{16}$ In fact, public morals enabled the public authority to restrict some freedoms, even though this situation did not benefit from legal recognition.

Finally, the most resounding example is, without doubt, the Commune de Morsangsur-Orge judgment, referred to as the 'midget-tossing', of 27 October 1995. A company organising events hired a midget. His job, the remuneration of which was legally laid down by a contract, consisted in getting thrown like a simple bag by the participants during a party in the disco. This activity did not represent any material danger neither for the spectators, nor for the participants, nor even for the midget, because he was thrown onto a mattress and was fitted with the adequate safety pads. Furthermore, there was no doubt that the person concerned endorsed the show in principle, since he gave his full consent. The mayor, nevertheless, banned this activity because he felt that it violated human dignity.

On appeal, the State Council declared the prohibition valid, considering that 'the regional public authority may (...) prohibit an attraction that violates the respect of human dignity', 'the respect of human dignity [being] a constituent element of the public order'. A few months before the decision of the Council of State, the principle of human dignity was legally recognised by the Constitutional Council as a principle of constitutional value. ${ }^{17}$ However, the link between this principle and the concept of the public order was not established, and the public authority continued to base its interventions on the material public order, pursuing the preservation of public security, hygiene and tranquillity, which did not play any role in the midget-tossing case. ${ }^{18}$ In that judgment, the administrative judge used the non-material dimension of the public order so as to respond to a situation that the existing law was not able to regulate.

Hence, the immaterial public order has been used in the past as a response to an extraordinary situation that the law does not take into account a priori. The concept is still in use today and is gradually getting formalised.

${ }^{14}$ Club indépendant sportif châlonnais (Council of State, 7 November 1924).

15 Beaugé (Council of State, 30 May 1930).

16 Sté Les Films Lutétia (Council of State, 18 December 1959).

17 Law on the Respect for the Human Body and Law on the Donation and the Use of Parts and Products of the Human Body, Medically Assisted Procreation and Prenatal Diagnosis no 1994343/344 DC (Constitutional Council, 27 July 1994)

The preamble to the 1946 Constitution reaffirmed and proclaimed rights, freedoms and constitutional principles, declaring in its opening paragraph: "In the morrow of the victory achieved by the free peoples over the regimes that had sought to enslave and degrade humanity, the people of France proclaim anew that each human being, without distinction of race, religion or creed, possesses sacred and inalienable rights"; it follows that the protection of human dignity against all forms of enslavement or degradation is a principle of constitutional status;

18 Article L. 2212-2 of the Local Authorities General Code. 


\subsection{Gradually Formalised Response}

Two cases marked an important return of the immaterial public order. The more recent of the two is the case of the French 'comedian', M. DIEUDONNÉ M'BALA M'BALA, whose performance was banned in the beginning of 2014 by certain prefects who felt that he would jeopardise public order. The matter was referred to the administrative judge of the Council of State, who validated the legality of the prohibition of the prefect, holding that the performance presented certain statements considered to be 'of a nature to question national cohesion' and likely to severely violate human dignity. ${ }^{19}$ The link with the aforementioned judgment Commune de Morsang-sur-Orge is clearly assumed by the judge who, in addition to assigning a central place to human dignity in their reasoning, explicitly included the midget-tossing judgement in the endorsement of their order.

However, the most interesting case is that of the law prohibiting the concealment of the face in public spaces. Judging that concealing one's face under integral veil or a combination of clothes was contrary to a social code that requires in France that one should 'hide their genitals and show their face', ${ }^{20}$ the legislator reacted by prohibiting this practice and imposing a fine on it. The Constitutional Council, seized in September 2010, before the law came into force, declared it constitutional, at the end of a revision, which was as short as surprising. In fact, even though the law limited several constitutional individual freedoms, the Constitutional Council chose to reiterate the arguments of the legislator, likewise considering that in so far as the practice of concealing one's face 'disregarded the minimum requirements of life in society', the objective of protecting the public order allowed to prohibit it. Thus, the Constitutional Council created a link between the public order and the 'minimum requirements of life in society', a legally non-defined element, which refers to social codes, bringing about an important consequence. These 'minimum requirements of life in society', which are integrated into the public order, can be protected by the legislator. In so far as the failure to respect them does not lead inevitably to material issues, their integration in the public order amounts to the recognition of the existence of an immaterial dimension to this concept. Thus, the immaterial public order is a sort of legal response to a social question. This is confirmed by the Constitutional Council's decision: the conciliation and the proportionality test, usually carried out with care in the field of individual freedoms, went practically without mention, the goal of protecting the immaterial public order justifying the constitutionality of the law.

However, the most interesting element of the Constitutional Council's decision is, no doubt, the reference to Article 5 of the Declaration of the Rights of Man and of the Citizen, which provides that 'Law can only prohibit such actions as are hurtful to society'. This reference, which formalizes the immaterial public order by giving it a textual constitutional base, shows that the legislator can intervene in order to defend society in the event of crisis, that is, when the exercise of individual freedoms interferes with one of its interests.

This solution resonated with the judgment of the ECHR in SAS vs. France, in which the Court found that the law prohibiting the concealment of the face in public spaces was in compliance with the Convention and enshrined the integration of 'the minimum requirements of life in society', in other words 'living together', in the Convention as

19 Ministre de l'intérieur c. Société Les Productions de la Plume et M. Dieudonné M'Bala M'Bala no 374508 (Council of State, ord., 9 January 2014).

20 Carcassonne, Guy, audition in Gérin, André and Raoult, Éric, Rapport d'information fait au nom de la mission d'information sur la pratique du port du voile intégral sur le territoire national (National Assembly 2010), n²262. 
legitimate grounds for not giving effect to the objects of the Convention. ${ }^{21}$ In fact, the Court considered that 'It indeed falls within the powers of the State to secure the conditions whereby individuals can live together in their diversity'22 and found that 'the impugned ban can be regarded as justified in its principle solely in so far as it seeks to guarantee the conditions of "living together", ${ }^{23}$

Used by the public authority and the legislator, consolidated by the constitutional judge and confirmed by the conventional judge, the concept of immaterial public order constitutes a legal response to a society challenged by the high-handed exercise of individual rights and freedoms. The immaterial public order is also a tool to regulate the relationship between normative authorities.

\section{USING THE IMMATERIAL PUBLIC ORDER AS A REGULATORY INSTRUMENT OF NORMATIVE AUTHORITIES}

Used as a last resort by the competent legal actors when the classic concepts are not sufficient to tackle the challenges society is facing, the immaterial public order is taken into account by legislation on recent issues. These issues include the resistance of the nation state to supranational communities like the European Union and the Council of Europe, but also the increasing power of the judge that results in upheavals, to which the immaterial public order attempts to respond. This concept permits to regulate existing relationships between legal orders (3.1), as well as between legislator and judge (3.2).

${ }^{21}$ SAS vs. France no 43835/11 (ECtHR, 1 July 2014)

Thirdly the Court found, however, that in certain circumstances, what the Government qualifies as compliance with the minimum requirements of life in society - the living together, in the explanatory memorandum of the draft law (see paragraph 25 above) - might be linked to the legitimate goal that constitutes the protection of the rights and freedoms of others. The Court takes into consideration the fact that the defendant State considers that the face has an important role in social interaction. The Court understands the point of view that individuals in public spaces do not wish that practices or attitudes fundamentally challenging the possibility of open interpersonal relations that, based on an established consensus, are an indispensable element of life together in the given society should develop. Nonetheless, the flexibility of the concept life together and the risk of excess that results from it require that the Court proceed to a careful review of the need for the impugned ban.

22 SAS vs. France no 43835/11 (ECtHR, 1 July 2014)

The Court observes that the authorities placed great emphasis on an objective. This emerges, in particular, from the explanatory memorandum accompanying the draft law, which indicates that The voluntary and systematic concealment of the face is problematic because it is quite simply incompatible with the fundamental requirements of 'living together' in French society, and The systematic concealment of the face in public places, contrary to the ideal of fraternity, also falls short of the minimum requirement of civility that is necessary for social interaction (see paragraph 25 above). It indeed falls within the powers of the State to secure the conditions whereby individuals can live together in their diversity. Moreover, the Court is able to accept that a State may find it essential to give particular weight in this connection to the interaction between individuals and may consider this to be adversely affected by the fact that some conceal their faces in public places (see paragraph 122 above).

${ }^{23} S A S$ vs. France no 43835/11 (ECtHR, 1 July 2014) 'Consequently, the Court finds that the impugned ban can be regarded as justified in its principle solely in so far as it seeks to guarantee the conditions of 'living together'. 


\subsection{Regulating the Relationship between Legal Orders}

What enables to regard the immaterial public order as an instrument of the State to defend its autonomy against the European Union and the Council of Europe is the tendency of this concept to drive the Court of Justice of the European Union (CJEC or CJEU depending on the date of the judgment referred to) and the ECHR to let the Member State or the party keep all its competence.

The Omega judgment of 2004 rendered by the CJEC is a very revealing example. The German public authority had prohibited, based on the public order, a laser game in which the participants simulated homicide for amusement, and German authorities felt that such a game violated human dignity. Analyzing the national provision in the light of public order being the legitimate ground, the Court held that 'It is not indispensable in that respect for the restrictive measure issued by the authorities of a Member State to correspond to a conception shared by all Member States as regards the precise way in which the fundamental right or legitimate interest in question is to be protected' ${ }^{24}$ Thus, the Court left space to particular national circumstances, giving the State the possibility to invoke the concept of a principle or a right of their own to limit a freedom protected by the communities. Furthermore, verifying whether the conditions of necessity and of proportionality of the national measure are fulfilled, the Court specifies, "the provisions adopted are not excluded merely because one Member State has chosen a system of protection different from that adopted by another State'. ${ }^{25}$ In other words, it is not because Germany established a protection of dignity the other Member States do not share that the conditions of necessity and of proportionality are not fulfilled. Accordingly, as S. Hennette-Vauchez clarifies, 'since invoking a fundamental right is possible to stop the exercise of a fundamental economic right, including when the aforementioned fundamental right is understood in a specifically national sense (...), the door (re)opens to something like a final say on the top of the levels of national protection of fundamental rights' ${ }^{26}$ In this judgment, the fact that the Court of Justice included its reasoning with regard to the public order as legitimate ground led to the recognition of the competence of the State. The immaterial public order thus protected the Member State's competence against the structure of the European Union.

With regard to the aforementioned $S A S$ v. France judgment, the immaterial public order's similar impact can be identified at the level of the Council of Europe in so far as the ECHR not only validates France's consideration for 'life together' as legitimate ground for

24 Omega C-36/02 (CJEC, 14 October 2004):

It is not indispensable in that respect for the restrictive measure issued by the authorities of a Member State to correspond to a conception shared by all Member States as regards the precise way in which the fundamental right or legitimate interest in question is to be protected. Although, in paragraph 60 of Schindler, the Court referred to moral, religious or cultural considerations which lead all Member States to make the organisation of lotteries and other games with money subject to restrictions, it was not its intention, by mentioning that common conception, to formulate a general criterion for assessing the proportionality of any national measure which restricts the exercise of an economic activity.

25 Omega C-36/02 (CJEC, 14 October 2004)

On the contrary, as is apparent from well-established case-law subsequent to Schindler, the need for, and proportionality of, the provisions adopted are not excluded merely because one Member State has chosen a system of protection different from that adopted by another State (see, to that effect, Läärä, paragraph 36; Zenatti, paragraph 34; Case C-6/01 Anomar and Others [2003] ECR I-0000, paragraph 80).

26 Hennette-Vauchez (2010) 790. See also Constantinesco (2010) 79. 
limiting a freedom guaranteed in the Convention, but also in so far as the proportionality test carried out by the Court is very limited, even neutralized. In fact, after having recognized that the State had considerable leeway because of the 'social nature' of the ban, the Court only reiterates that if the criminal sanctions arising from the ban are light, the ban is proportionate ${ }^{27}$ in other words, the lightness alone prevails in the proportionality of the measure. Here again, the immaterial public order enabled the State to impose its full jurisdiction against the supranational level.

This defense function can be found internally, as the immaterial public order rehabilitates the legislative function as opposed to the jurisdictional function.

\subsection{Regulating the Relationship between Legislator and Constitutional Judge}

Just like the proportionality test of the ECJ and the ECHR was limited, the French constitutional judge's tool of proportionality testing is neutralised in the context of a measure based on the immaterial public order.

The Constitutional Council, in its decision on the law prohibiting the concealment of the face in public spaces, limited itself to control only obvious imbalances, judging that 'in view of the introduced measure (...), the legislator adopted provisions ensuring a conciliation not overly disproportionate between the protection of the public order and the guarantee of constitutional rights'. ${ }^{28}$ In fact, the legislator provided only for a fine, not for a prison sentence. Nevertheless, it is not certain that the decision would have been any different in the case of a sanction of a different nature (for example, a custodial sentence). There is room for doubt, in so far as the Belgian Constitutional Court, when confronted with a similar law containing a more severe sanction, considered the punishment proportionate, 'since the legislator opted for the lightest of criminal penalties' ${ }^{29}$ The criminal sanction was

27 SAS vs. France no 43835/11 (ECtHR, 1 July 2014). The Court points out, in fact, 'It should nevertheless be taken into account that the sanctions provided for by the Law's drafters are among the lightest that could be envisaged'.

28 Law on prohibiting the concealment of the face in public spaces no 2010-613 DC (Constitutional Council, 7 October 2010)

Considering that in view of the objectives the legislator has set for itself and taking into account the nature of the penalty introduced in the event of the infringement of the rule laid down by it, the legislator adopted provisions ensuring a conciliation not overly disproportionate between the protection of the public order and the guarantee of constitutional rights; that, however, prohibiting the concealment of the face in public spaces could not restrict the exercise of religious freedom in places of worship open to the public without excessively violating Article 10 of the Declaration of 1789; that, subject to this caveat, Articles 1 and 3 of the law referred are not unconstitutional.

29 No 145/2012 (Belgian Constitutional Court, 6 December 2012)

Since the identification of people, in which the face plays a fundamental role, constitutes an essential condition of the functioning of a democratic society, every member of which is a legal subject, the legislator could consider that the concealment of the face could endanger the functioning of the society thus designed and thus has to be criminally punishable. Subject to the provisions under B.30, in so far as it is oriented to those who freely and willingly conceal their face in spaces accessible to the public, the impugned measure does not have disproportionate effects as regards the aims being pursued, since the legislator opted for the lightest of criminal penalties. The circumstance that the punishment can be more severe in the case of repeated violations does not lead to a different conclusion. The legislator could, in fact, hold that an offender condemned for such behaviour and criminally sanctioned would not repeat this behaviour, under threat of a more severe sentence. 
a prison sentence of one to seven years... The comparison of these two decisions shows that the nature of the sanction, as it is the case of the consent of the person whose liberty has been restricted, has no effect when balanced against the immaterial public order; in reality, the constitutional judge, French or Belgian, is limited by the objective on which the law is based, namely the protection of the immaterial public order. This self-limitation of the judge is, however, not illogical. In fact, even if the representative system is in crisis today, the legislator remains the decision maker. Consequently, facing a law expressing a society choice, the judge does not really have any other option but to rely on the discretionary power of the Parliament, and thus to remain below competence. In this regard, the immaterial public order enables the protection of legislative power against jurisdictional power the legitimacy of which has not yet been completely established.

Response to a society in crisis, protection of institutions in crisis, the concept of the immaterial public order turns the established legal tools at the disposition of the judges upside down and finally launches more challenges than it enables to tackle. The most important among these is, no doubt, the one to be faced by the judge who, surpassed by this concept, has no instruments to limit it. Without doubt, European judges will not have any other choice than to return to the principle of subsidiarity in matters concerning the immaterial public order, thus leaving to the State the fields in which the 'renationalisation' of their competences is favourable. As for the national judges, they could benefit from the fact that the legislator has not yet defined explicitly the concept in order to attempt to manage it by fixing its components and contours.

\section{LITERATURE}

Del Valle, Alexandre, Pour en finir avec le complexe occidental. Petit traité de déculpabilisation (Toucan 2014).

Guerrini, Marc, L'identité constitutionnelle de la France (PhD Thesis, University Aix-Marseille 2014).

Levade, Anne, 'Identité constitutionnelle et exigence existentielle. Comment concilier l'inconciliable', in Masclet, Jean-Claude, Ruiz Fabri, Hélène, Boutayeb, Chahira et Rodrigues, Stéphane (eds), L'Union européenne : Union de droit, Union des droits, Mélanges en l'honneur de Philippe Manin (Pedone 2010) 109-28.

Mathieu, Bertrand, Constitution: rien ne bouge et tout change (Lextenso 2013).

Millet, François-Xavier, L'Union européenne et l'identité constitutionnelle des États membres (LGDJ 2013).

Quesnel, Martin, La protection de l'identité constitutionnelle de la France (Dalloz 2015).

Hennette-Vauchez, Stéphanie, 'Les droits fondamentaux à Luxembourg. Droit et politique dans la détermination des contours de l'office du juge', in Masclet, Jean-Claude, Ruiz Fabri, Hélène, Boutayeb, Chahira et Rodrigues, Stéphane (eds), L'Union européenne: Union de droit, Union des droits, Mélanges en l'honneur de Philippe Manin (Pedone 2010) 775-94.

Constantinesco, Vlad, 'La confrontation entre identité constitutionnelle européenne et identités constitutionnelles nationales. Convergence ou contradiction? Contrepoint ou hiérarchie?', in Masclet, Jean-Claude, Ruiz Fabri, Hélène, Boutayeb, Chahira et Rodrigues, Stéphane (eds), L'Union européenne: Union de droit, Union des droits, Mélanges en l'honneur de Philippe Manin (Pedone 2010) 79-94. 